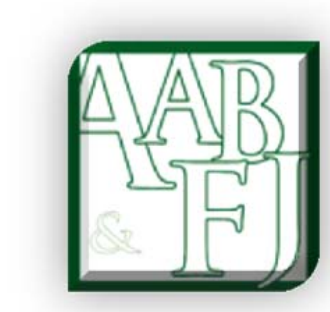

Technical Note

\title{
Changing from a Rules-based to a Principles-based Accounting Logic: A Review
}

\author{
Marta Silva Guerreiroํ, Lúcia Lima Rodrigues² \& Russell Craig ${ }^{3}$
}

\begin{abstract}
We explore influences on unlisted companies when Portugal moved from a code law, rules-based accounting system, to a principles-based accounting system of adapted International Financial Reporting Standards (IFRS). Institutionalisation of the new principles-based system was generally facilitated by a socio-economic and political context that increasingly supported IFRS logic. This helped central actors gain political opportunity, mobilise important allies, and accommodate major protagonists. The preparedness of unlisted companies to adopt the new IFRS-based accounting system voluntarily was explained by their desire to maintain social legitimacy. However, it was affected negatively by the embeddedness of rule-based practices in the 'old' prevailing institutional logic.
\end{abstract}

Keywords: Change, IFRS, institutional, Portugal, principles, rules

JEL Code(s): M41

\footnotetext{
${ }^{1}$ Polytechnic Institute of Viana do Castelo

${ }^{2}$ University of Minho

${ }^{3}$ Victoria University, Melbourne

e-mail: Russell.Craig@vu.edu.au
} 


\section{Introduction}

During the last decade, IFRS issued by the International Accounting Standards Board (IASB) have gained a very high level of acceptance throughout the world. IFRS are now mandatory for listed companies in member countries of the European Union (EU), and throughout most of the world, including in Australia, Brazil, Canada, Turkey, and South Africa - but not in the USA. (For a comprehensive summary of the adoption of IFRS by country, see http://www.iasplus.com/en/resources/ifrs-topics/use-of-ifrs, accessed 4 January 2014). IFRS are rapidly emerging as the globally accepted accounting standards framework. However, the processes and implications of adopting IFRS by individual countries have been underexplored. The review we conduct here fosters understanding of the institutional factors that have interacted in the social, cultural and political environments of European Latin country adopters of IFRS (including IFRS in adapted form).

Understanding the Portuguese setting will be instructive in assessing the broader situation in other European Latin countries (including Belgium and Luxembourg) - and, to a lesser extent, in other essentially rules-based societies, such as the USA. Traditionally, accounting in European Latin countries has been classified as rules-based, and regulated in detail (Mueller, Gernon \& Meek 1997; Nobes \& Parker, 2004; Salter \& Doupnik, 1992). The preparation of financial statements in those countries has been influenced strongly by tax law, and by the needs of banks and the State (Caria \& Rodrigues, 2014). Given this background, the decision of Portugal's Accounting Standards Board (Comissão de Normalização Contabilística - CNC) to revoke Portugal's rules-based Official Accounting Plan (Plano Oficial de Contabilidade - POC) provides a good contemporaneous opportunity to understand the reasons and means used by central actors in a highly institutionalised field to enact change in a national accounting system. It also provides an opportunity to reveal how entities dealt with the pressures of accounting change when Portugal introduced a system of accounting based largely on principles-based IFRS. The study findings we review yield potential explanatory insights to the slow progress of fundamental accounting regulation change in other traditionally rule-based accounting countries, such as the USA.

In the following review, we bring together three empirical studies we have conducted of the adoption of (adapted) IFRS in Portugal. These are published in leading peer-reviewed international accounting journals. However, each of the studies reviewed addresses a fractionated part of the larger phenomenon of significant accounting regime change. The objective of our present review is to distil the main findings of those studies into a coalescing and consolidating overview in which we offer fresh insights, introduce additional supporting literature, and present some informed and thought-provoking conjecture. Our aim is to enhance understanding of how and why IFRS became institutionalised. Whereas most empirical analysis in this topic area has focused on the behaviour of large listed companies, we contribute to understanding by focusing on the behaviour of large unlisted companies and small and medium sized entities (SMEs).

The powerful lens of institutional theory helps draw attention to the embeddedness of actors in wider social structures - a fundamental aspect of understanding how entrepreneurial action and institutional change evolves. This lens helps to highlight how various participants in society seek legitimacy by adopting institutional systems (such as accounting) that are consistent with wider social structures. Thus, it helps to explain the processes underlying adoption of a new IFRS-based system of accounting in terms of pressures of social legitimisation, rather than of economic logic or economic utility. We reveal how Portuguese unlisted companies and SMEs 
dealt with the obligation to apply an IFRS-based accounting system. We do so mindful that various institutional systems (legal, political, economic and accounting) are critical to economic and social intercourse in any civil society, and that these systems change over time.

\subsection{Aspects of the Adoption of IFRS}

Generally, the adoption of IFRS throughout the world has been a response to lobbying by capital markets regulators and the effects of globalisation, rather than a response to any specific government policy initiative (Whittington 2005). For many countries, the adoption of IFRS has heralded a change in the underlying rationale for accounting standards. This is because IFRS are founded on broad principles rather than on highly specific and detailed rules. Thus, the adoption of IFRS presents a major challenge in European Latin countries and other countries (such as the USA), where accounting procedures have been largely rules-based hitherto.

IFRS are designed to reflect economic gains and losses in a timely fashion, and to restrict the discretion allowable to manipulate provisions and create hidden reserves (Ball 2006; Jaruga et al. 2007). A key argument in support of IFRS is that they will lead to the reporting of financial information that is more relevant and comprehensive to investors than information arising from accounting standards used previously. Nonetheless, the likely benefits of adopting IFRS have been a matter of keen debate (see Chua \& Taylor 2008; Rodrigues \& Craig 2007). There is ample evidence that the capital market effects of mandatory adoption of IFRS are not distributed evenly across countries or among firms (Armstrong et al. 2010; Christensen et al. 2007; Daske et al. 2008); and that the mooted benefits are likely to be confounded by environmental differences, national idiosyncrasies, and the unique culture, politics, history, and embedded beliefs of individual countries (Chand \& Patel 2008). The complicated nature of IFRS, and the tax-oriented nature of many national accounting systems, have also provided major barriers to adoption (Callao, Jarne \& Lainez 2007; Larson \& Street 2004).

Currently, China and the USA, together with several other countries, are engaged in projects intended to converge their national accounting standards with IFRS (for example, China Briefing 2013). In November 2007, in the USA, the Securities and Exchange Commission (SEC) strongly endorsed IFRS by allowing foreign private companies to adopt IFRS in financial statements lodged with the SEC, without requiring a reconciliation of the IFRS data with US GAAP. However, subsequent progress towards full implementation of IFRS in the USA has been slow and sporadic.

In 2012, a final SEC staff report (which had been delayed repeatedly) made it clear that the adoption of IFRS by US companies was not a matter of "when”, but "whether" (Rosivach 2012). According to Norris (2012, n.p.), "American enthusiasm for international accounting standards appears to have waned.” The reasons appear to be concerns by domestic US companies about the costs involved; fears by auditing firms that they will be subject to a profusion of lawsuits in the litigious US society; and a mixture of national hubris and xenophobia arising from having US accounting standards being set in the UK with a strong European influence (McKay 2010; Norris 2012).

In EU member countries, commencing in January 2005, more than 8,000 listed companies were required to adopt IFRS when preparing their consolidated financial statements. Attempts to develop a common system of accounting in Europe have a long history. The EU's Fourth Directive (issued in 1978) and the Seventh Directive (issued in 1983) sought to harmonise accounting regulations in EU countries. However, the changes proposed in these Directives were 
matters of form rather than substance (Emenyonu \& Gray 1992; Haller \& Kepler 2002; Joos \& Lang 1994). The European Commission (EC) acknowledged that these accounting directives did not ensure the high levels of comparability and transparency required to build an efficient, integrated and globally competitive capital market. In 2002, EC Regulation 1606/2002 required IFRS to be used by publicly-traded companies from 1 January 2005 in preparing consolidated financial statements. Each country in the EU was left to consider whether (and if so how) to apply this obligation for entities other than publicly-traded companies. Thus, EU countries were confronted with a decision on whether or not to permit the use of IFRS in the annual accounts of all entities; in the annual accounts of listed companies only; or in all consolidated accounts. (Information about the decisions of individual EU member-states is available at http://ec.europa.eu/internal_market/accounting/docs/ias/ias-use-of-options_en.pdf, accessed 8 April 2014).

In accord with the emerging global trend and the European context, the Portuguese government decreed that effective from 1 January 2010, Portugal's rules-based Official Accounting Plan (POC) would be revoked and a new accounting system would be adopted (Decree-law 158/2009, July). The new accounting system was called the Accounting Standardisation System (Sistema de Normalização Contabilística - or SNC). It applied to unlisted companies and SMEs and permitted a choice between adopting a set of 28 accounting standards based on IFRS (with some adaptations) or one simplified accounting standard for SMEs.

The remainder of this paper is devoted to an interpretive review of our three studies, using institutional theory as the analytical frame. In analysing these studies as a cohering corpus of work, the intent is to render deeper understandings of institutional pressures, institutional dynamics, the relative power of actors, and the change processes that occurred in Portugal. Importantly, we provide implicit and explicit explanatory insights to experiences in other countries. The following review should develop understanding of how accounting systems and structures adopted in any country reflect that country's prevailing rules, norms and cultural beliefs; and how accounting systems and structures are perceived as helping to deliver social legitimacy to business entities.

\section{An Institutional Theory View of the Adoption of IFRS and the Sistema De Normalização Contabilística (SNC) in Portugal in 2010}

Full understanding of the institutionalisation process of a new accounting system must consider the links between practices at the organisational level and the organisational field level; the influence of higher social, political and economic levels on the organisational context; and the role of influential actors. In Guerreiro, Rodrigues and Craig (2014), we used Dillard, Rigsby and Goodman's (2004) institutional change model to analyse the process of accounting change that occurred in Portugal with the adoption of the SNC in 2010. We explored the institutional dynamics that flowed between the political and economic level within which the SNC was established; the organisational field level of professional and business associations; and the organisational level of individual accountants of SMEs. We highlighted the gradual transformation of meanings and criteria that occurred in each of these three levels; and revealed how actions of various agents influenced outcomes.

We conducted semi-structured interviews with members of the CNC, the representative of the CNC on the Accounting Regulatory Committee of the EC, the President of the official 
professional accounting association in Portugal, Ordem dos Técnicos Oficiais de Contas (OTOC), the President of the official auditors association, Ordem dos Revisores Oficiais de Contas (OROC), representatives on the CNC of the Portuguese Confederation of Commerce and Services, Confederation of Portuguese Farmers, and Portuguese Confederation of Manufacturing, and eight accountants of SMEs. These interviews explored the top-down deinstitutionalisation of the POC and its replacement through the institutionalisation of the SNC. We wanted to enhance understandings of the change processes involved in moving from national to international accounting standards.

The international movement towards IASB standards led to regulatory changes within the EU. These introduced new accounting criteria and new legitimating structures that valued the decision usefulness of financial statements. They disturbed the professional consensus in codelaw countries: awareness of an alternative accounting logic gradually became widespread. This disturbance enabled the CNC to act as an institutional entrepreneur. Its role was facilitated by the embeddedness of important actors in multiple fields (e.g. the Minister of Finance and members of the executive committee of the CNC had work experience with listed multinational companies). Nonetheless, the adoption of the SNC implied exchange mechanisms and collaborative relations between the CNC and OTOC and OROC. Adoption required accommodating the interests of the main actors at the organisational field level (e.g., limits for use of the SME standard established which entities were permitted to adopt this simplified accounting system. These limits were negotiated to accommodate interests of members of the major accounting associations).

A principal finding was that the cascading institutionalisation process explained by Dillard et al. (2004) can invert at an earlier stage. Specifically, positions taken by professional accounting associations and other organised parties reflected operating practices that are considered legitimate at the organisational field level. These positions influenced regulations enacted at the political and economic level at an earlier stage than envisaged by Dillard et al. (2004): that is, agents at the organisational field level (the accounting and auditing professions, and business associations) counteracted the institutionalisation process before it reached the organisational level (SMEs).

These findings point to the need for better understanding of the significant role that national professional accounting associations can play in shaping criteria established at the political and economic level. According to Guerreiro et al. (2014), in the accounting standardsetting context, some actors can be involved influentially in all three levels of the Dillard et al. (2004) model. Accountants and accounting firms (organisational level) have representatives at OTOC (organisational field level), and this organisation has representatives at the CNC (political level). Such multi-level representativeness, which is present in the accounting domain in most countries, facilitates the inter-level dynamics proposed by Dillard et al. (2004). It helps explain why pressures for change can move upwards and downwards in the societal system; and it reinforces the applicability of the Dillard et al. (2004) model in the accounting domain.

At the organisational level, the SNC was adopted in two different ways. Some Portuguese accountants with only small clients chose to adopt the Portuguese SME standard. These accountants maintained the accounting practices and representational schema of the previous rules-based accounting system (POC) when framing new situations. The ceremonial adoption of the SNC by these accountants is explained mainly by a perceived efficiency gap. Adoption was influenced by thinking that the SNC ultimately reflected the goals and needs of multinational corporations and capital markets, and that this conflicted with the interests and needs of clients of 
these accounting firms. For accountants in small firms, loose coupling of the SNC helped reduce the impact of accounting change and maintain a degree of institutional stability.

However, accountants with a heterogeneous client list who adopted the general regime of the SNC (28 specific accounting standards) responded differently. For these accountants, institutional contradictions were smaller and the needs of their clients were better addressed by the timelier, more value-relevant, and less conservative accounting system of the 28 SNC standards. They welcomed the opportunities the SNC provided to rethink important accounting concepts, and to change their signification schema and legitimating grounds.

The CNC's enforcement system, and the quality control mechanisms of professional associations, encouraged companies to change their accounting practices. Nonetheless, embrace of an accounting system grounded in an Anglo-Saxon institutional logic, and focused on a principles-based approach, was only possible if accompanied by a gradual transformation of legitimating structures in the evolving social environment.

These conclusions are consistent with the main findings of Guerreiro, Rodrigues and Craig (2012a) that pertain to the preparedness of large unlisted companies to implement the SNC. In the Guerreiro et al. (2012a) study, we reported on our survey of 116 large unlisted Portuguese companies, in September 2009, that sought to identify important institutional factors affecting the preparedness of these companies to adopt the SNC; and the reasons for the low level of preparedness found. The institutional theory perspective we adopted accommodated change, strategic choice, organisational resistance, and institutional logics.

Institutional factors with a positive influence on the degree of preparedness of large unlisted companies to adopt the SNC on 1 January 2010 included: parent company participation in conversion procedure decisions (by encouraging subsidiary companies to adopt accounting procedures that accorded with the needs of the ultimate parent owners); the presence of exclusively Portuguese shareholders (companies with only Portuguese owners were better prepared because they have higher expectations about the success of the conversion process due to legitimacy concerns); and the conduct of export activities (these encourage mimicking of the practices of successful organisations in the organisational fields of export organisations). Nonetheless, the degree of preparedness found was low. In preparing for transition to the new accounting system, companies had not yet developed the necessary degree of consensus regarding the value of the SNC. Additionally, preparedness was undermined by resistance within the Portuguese accounting profession. This is explained by the embeddedness of rule-based practices in the prevailing code-law institutional logic, and the consequent lack of normative rules capable of guiding professional behaviour towards adoption of the SNC.

We drew attention to the prospect that accounting practices were "historically rooted institutional logics (that) establish appropriate ways for individuals and organisations to behave"; and that, in the US "the adoption of IFRS demands moving from a rules-based logic to a principles-based logic” (Guerreiro et al. 2012a, p.182). We also drew attention to the prospect that such a change "is not welcome by some important institutional constituents, as demonstrated recently for investors by McEnroe and Sullivan (2011)” (p. 182). We noted that “in May 2011, the IFRS Readiness Survey by the AICPA (http://www.aicpa.org/Research/StudiesandPapers/DownloadableDocuments/IFRS\%20Readines s\%20Survey\%20-Spring\%202011\%20-\%20public.pdf, accessed on 1 July 2011) reported that approximately $80 \%$ of surveyed (US) organisations were unprepared to implement IFRS or had yet to start implementing any IFRS convergence plan” (p.182). 
In Guerreiro et al. (2012b), we sought to explain voluntary adoption of IFRS by Portuguese companies, before the imposition of the SNC, by exploring which of Oliver's (1991) strategic responses (acquiesce, compromise, avoid, defy, manipulate) best described this behaviour. We introduced new theoretical arguments to explain how institutional pressures influenced company decisions to adopt IFRS voluntarily in individual accounts in the period 2005-2009. We combined the concept of institutional logics with Oliver's (1991) analytical framework and applied this framework to financial accounting. We contended that explanation of voluntary adoption of IFRS should account for the prevailing institutional logics in which the interests and values of individuals and organisations are embedded; and that broader belief systems are fundamental in understanding the willingness of organisations to conform to institutional pressures.

Our 158 questionnaire responses revealed that companies were willing to change from a code-law, essentially rules-based institutional logic, to a common-law, essentially principlesbased institutional logic, if they considered such a change would have positive overall benefits to them. Companies assessed the net benefits of change after considering the legitimacy they were likely to achieve with IFRS; the consistency of IFRS with their goals and institutional context; and the loss of autonomy they would be likely to sustain from adopting IFRS. The adoption of IFRS was perceived as a way for organisations to increase prestige by demonstrating social fitness and consistency with the expectations of those of their institutional constituents who associate IFRS with high quality accounting information. Other important explanatory factors found to influence the voluntary adoption of IFRS included resource-dependence, consistency with internal goals, connectedness with the organisational field, and environmental uncertainty.

Nonetheless, the companies adopting IFRS voluntarily assigned those standards a lower degree of autonomy in their decision-making than they assigned to standards in the national system. However, in Guerreiro et al. (2012b) we found that the loss of autonomy resulting from the adoption of IFRS was much less important for large unlisted companies than other factors: enhancing their legitimacy, meeting their constituents' expectations and organisational goals, overcoming environmental uncertainty and being consistent with the requirements of a highly interconnected environment. Consequently, voluntary adoption of IFRS was seen as a strategic organisational response to institutional pressures and not a blind response. That is, companies evaluated the pressures with which they wanted to acquiesce, and promoted their self-interests when responding to institutional pressures. The higher level of constraints imposed by IFRS provides opportunity for loose coupling according to Oliver's (1991) framework. Companies had the opportunity to adopt IFRS voluntarily, but nonetheless maintain the regime of accounting standards in a way that is detached from accounting practices. The incentive for them to do so was helped by the fact that the requirements imposed by IFRS differed significantly from those of code law logic.

Our findings enhance understanding of the type of unlisted companies that are likely to need encouragement to adopt a new mandatory regime of accounting standards. This knowledge should be beneficial to standard setters, regulators, governments, and businesses and professional accounting associations in countries that are yet to adopt IFRS for unlisted companies. 


\section{Discussion}

IASB standards have become the dominant logic of transnational accounting regulation (Suddaby, Cooper \& Greenwood 2007). In Europe, legitimating, signification and domination structures have changed accordingly at the political and economic level. This has led EU countries (such as Portugal) to develop new accounting systems based on EU-endorsed IFRS.

The new SNC accounting system in Portugal was developed at the political level through the mobilisation of powerful actors in dominant positions at the organisational field level (such as professional and business associations). The new institutional logic was embraced readily by the higher levels of Portuguese society (the political and economic level and the organisational level) because it accorded with the interests of agents of these levels. The main institutional entrepreneur (CNC) played an important part in initiating and theorising the process of change, and in harnessing political support by mobilising allies. Gradually, criteria and practices changed.

However, lower-order logics, such as common-law versus code-law logics, are fundamental in prescribing local accounting practices. Thus, even though the features of the new accounting system reflected the interests of actors in the organisational field, full compliance did not occur. Accountants with only small clients adopted the SME standard that allowed them to maintain the old signification and legitimation structures. While adoption of the Portuguese SME accounting standard favoured transference of accounting concepts from the previous system, full adoption of the SNC standards (the 28 accounting standards of the general regime) favored tight coupling and de facto application of principles-based accounting standards. Even though it demanded a greater preparation effort during the transition period (by all companies and by all accountants), full adoption of IFRS-type standards facilitated changes in signification and legitimation structures at the organisational level. This led to consistent adoption of these standards. By understanding the institutional elements associated with successful instances of preparedness to adopt IFRS (or adapted IFRS), standard setters, regulators, governments, business and professional accounting associations will be better placed to identify the type of unlisted companies that are likely to need encouragement to comply with such a regime of accounting standards.

Our three studies found that the evolution of an organisation's accounting practices can be shaped strongly by coercive and mimetic pressures. We recommend that attention be paid to the prospect that normative embeddedness, and competing institutional logics, will be sources of organisational resistance to broad-scale institutional changes during the preparation phase for adoption of a new accounting regime. Normative embeddedness is likely to be more difficult to overcome due to the taken-for-grantedness of old values and rules, and the embeddedness of those rules and values in the prevailing institutional logic (Guerreiro et al. 2012a). Such embeddedness helps to explain the reluctance and tardiness of the rules-based accounting profession in the USA to finally and unequivocally adopt a principles-based system of accounting based on IFRS.

Portuguese companies were willing to voluntarily change from a rules-based (code-law) institutional logic to an essentially principles-based (common-law) (IFRS) institutional logic, if this cohered with the institutional pressures they chose to comply with. Companies were motivated to change in order to enhance their legitimacy, meet their constituents' expectations and organisational goals, overcome environmental uncertainty, and to conform to the requirements of a highly interconnected environment. The strategies companies may exhibit in 
response to institutional pressures to adopt IFRS range from conformity to active resistance. In Portugal, voluntary adoption of IFRS was a strategic response that reflected acquiescence to institutional elements, notwithstanding the possibility of avoidance strategies (decoupling). Their choice of strategy depended on the strength and relative importance of such institutional pressures to them.

The post-IFRS implementation phase in countries that have adopted IFRS offers several important areas for future research. There needs to be a closer understanding of the evolving trade-off between transnational and national regulatory structures; and of the way new accounting practices emerge, are diffused, and subsequently decline. Such further investigations will improve understanding of how accounting changes are institutionalised in national and international settings. They will enable the development of more mature and informed understandings of the likely response of accountants and accounting-related institutions to any future proposals to change accounting regimes.

\section{References}

Armstrong, CS, Barth, ME, Jagolinzer, AD \& Riedl, EJ 2010. 'Market reaction to the adoption of IFRS in Europe', Accounting Review, vol.85, pp31-61. http://dx.doi.org/10.2308/accr.2010.85.1.31

Ball, R 2006, International Financial Reporting Standards IFRS: Pros and cons for investors. Accounting and Business Research, 36: sup1, pp5-27.

Callao, S, Jarne, J \& Laínez, JA 2007, 'Adoption of IFRS in Spain: Effect on the comparability and relevance of financial reporting', Journal of International Accounting, Auditing \& Taxation, vol.16, pp148-178. http://dx.doi.org/10.1016/j.intaccaudtax.2007.06.002

Caria, A \& Rodrigues, LL 2014, 'The evolution of financial accounting in Portugal since the 1960s: a new institutional economic perspective', Accounting History, vol.19, pp227 254. http://dx.doi.org/10.1177/1032373213511319

Chand, P \& Patel, C 2008. 'Convergence and harmonization of accounting standards in the South Pacific region', Advances in Accounting, Incorporating Advances in International Accounting, vol.24, pp83-92.

China Briefing 2013, China GAAP vs. U.S. GAAP and IFRS, accessed 18/2/2014 http:/www.china-briefing.com/news/2013/02/05/china-gaap-vs-u-s-gaap-and-ifrs.html,

Christensen, HB, Lee, E \& Walker, M 2007, 'Cross-sectional variation in the economic consequences of international accounting harmonization: The case of mandatory IFRS adoption in the UK', International Journal of Accounting, vol.42, pp341-379.

Chua, WF \& Taylor, SL 2008, 'The rise and rise of IFRS: An examination of IFRS diffusion', Journal of Accounting and Public Policy, vol.27, pp462-473. http://dx.doi.org/10.1016/j.jaccpubpol.2008.09.004

Daske, H, Hail, L, Leuz, C \& Verdi, R 2008, 'Mandatory IFRS reporting around the world: Early evidence on the economic consequences', Journal of Accounting Research, vol.46, pp 1085-1142.

Dillard, JF, Rigsby, JT \& Goodman, C 2004, 'The making and remaking of organization context: Duality and the institutionalization process', Accounting, Auditing \& Accountability Journal, vol.17, pp506-542. http://dx.doi.org/10.1108/09513570410554542 
Emenyonu, EN \& Gray, SJ 1992, 'EC accounting harmonisation: An empirical study of measurement practices in France, Germany and the U.K', Accounting and Business Research, vol.23, pp48-52.

Guerreiro, MS, Rodrigues, LL \& Craig R 2012a, 'Factors influencing the preparedness of large unlisted companies to implement adapted International Financial Reporting Standards in Portugal', Journal of International Accounting, Auditing and Taxation, vol.21, pp169184. http://dx.doi.org/10.1016/j.intaccaudtax.2012.07.006

Guerreiro, MS, Rodrigues, LL \& Craig R 2012b, 'Voluntary adoption of International Financial Reporting Standards by large unlisted companies in Portugal - institutional logics and strategic responses', Accounting, Organizations \& Society, vol.37, pp482-499. http://dx.doi.org/10.1016/j.aos.2012.05.003

Guerreiro, MS, Rodrigues, LL \& Craig R 2014, 'Institutional analysis of a new accounting regime: Implications for Portuguese SMEs of adoption of adapted International Financial Reporting Standards', European Accounting Review, accessed 04/06/2014, http://www.tandfonline.com/doi/pdf/10.1080/09638180.2014.887477.

Haller, A \& Kepler, J 2002, 'Financial accounting developments in the European Union: Past events and future prospects', European Accounting Review, vol.11, pp153-190. http://dx.doi.org/10.1080/09638180220124770

Jaruga, A, Fijalkowska, J, Jaruga-Baranowska, M \& Frendzel, M 2007, 'The impact of IAS/IFRS on Polish accounting regulations and their practical implementation in Poland', Accounting in Europe, vol.4, pp67-78. http://dx.doi.org/10.1080/17449480701308675

Joos, P \& Lang, M 1994, 'The effects of accounting diversity: Evidence from the European Union', Journal of Accounting Research, vol.32, pp141-168. http://dx.doi.org/10.2307/2491444

Larson, RK \& Street, DL 2004, 'Convergence with IFRS in an expanding Europe: Progress and obstacles identified by large accounting firms' survey', Journal of International Accounting, Auditing \& Taxation, vol.13, pp89-119. http://dx.doi.org/10.1016/j.intaccaudtax.2004.09.002

McKay, M 2010, Why IFRS adoption will slow down in the U.S., accessed 20/3/2014 http://acctgprinciples.blogspot.com.au/2010/01/why-ifrs-adoption-will-slow-down-inus.html.

McEnroe, JE, \& Sullivan, M 2011, 'Individual investors' attitudes toward the acceptance of International Financial Reporting Standards in the United States', Journal of International Accounting, Auditing and Taxation, vol.20, pp20-31. http://dx.doi.org/10.1016/j.intaccaudtax.2010.12.002

Mueller, G, Gernon, H \& Meek, G 1997. Accounting: An International Perspective, Irwin, Boston, MA.

Nobes, C \& Parker, R 2004', Comparative International Accounting, Prentice Hall, London.

Norris, F 2012, 'IFRS not supported by US markets: SEC', Financial Review, 16 July, accessed 19/2/1014

http://www.afr.com/f/free/markets/capital/cfo/ifrs_not_supported_by_us_markets_Zc22ht lMOa1NxcQu5n634K.

Oliver, C 1991, 'Strategic responses to institutional processes', Academy of Management Review, vol.16, pp145-179. 
Rodrigues, LL \& Craig, R 2007, 'Assessing international accounting harmonization using Hegelian dialectic, isomorphism and Foucault', Critical Perspectives on Accounting, vol.18, 739-757. http://dx.doi.org/10.1016/j.cpa.2006.02.007

Rosivach, A 2012, 'Not a good year for IFRS adoption in the US', Accountingweb, accessed 19/2/2014 http://www.accountngweb.com/article/not-good-year-ifrs-adoption-us/220564.

Salter, SB \& Doupnik, TS 1992, 'The relationship between legal systems and accounting practices: A classification exercise', Advances in International Accounting, vol.5, pp3-22.

Suddaby, R, Cooper, DJ \& Greenwood, R 2007, 'Transnational regulation of professional services: Governance dynamics of field level organizational change. Accounting, Organizations and Society, vol.32, pp333-362. http://dx.doi.org/10.1016/j.aos.2006.08.002

Whittington, G 2005, 'The adoption of International Accounting Standards in the European Union', European Accounting Review, vol.14, pp127-153. http://dx.doi.org/10.1080/0963818042000338022 